\title{
ALL-FEMALE BROODS IN THE POLYMORPHIC BUTTERFLY DANAUS CHRYSIPPUS L. AND THEIR ECOLOGICAL SIGNIFICANCE
}

\author{
D. A. S. SMITH \\ University of Dar Es Salaam, P.O. Box 35064, Dar Es Salaam, Tanzania
}

Received 4.vi.74

\begin{abstract}
SUMmary
Many female Danaus chrysippus produce all-female broods. Of the two common colour forms at Dar-es-Salaam, Tanzania, form dorippus usually gives normal broods while more than 50 per cent of form chrysippus tested produced all-female broods. It is suggested that all-female broods are the result of meiotic drive governed by a Y-linked gene and that a dominant autosomal suppressor, closely linked with the forewing colour locus, must be present in the population. As selection for the colour morphs changes with season, the sex ratio also alternates between an excess of females at the start of the rains when population density increases rapidly, and an excess of males, probably through superior survival, in the driest months. Changes in sex ratio allow the population to alter its numbers very quickly in response to prevailing conditions.
\end{abstract}

\section{INTRODUCTION}

Owen AND Chanter (1968) first reported all-female broods in Danaus chrysippus (Danaidae) at Makerere, Uganda, where 11 out of 20 batches of eggs obtained from wild females produced only female offspring. They attributed the excess of females in the field, which was statistically significant, to this fact. All 18 broods reared at Freetown, Sierra Leone, had a normal sex ratio (Chanter and Owen, 1972) and no other cases of all-female broods have been reported for $D$. chrysippus. In this paper, I give the results with respect to sex ratio of rearing 51 broods of $D$. chrysippus at Dar-es-Salaam, Tanzania, and show that the inheritance of sex ratio interacts with that of the colour polymorphism with important genetic and ecological consequences.

\section{Materials AND Methods}

Four colour forms of $D$. chrysippus are present in the population studied on the campus of the University of Dar-es-Salaam. Forms chrysippus and dorippus (fig. 1) are common while the two forms with white hindwings, alcippus and albinus, are rare (Smith, 1973a). All the broods analysed here were obtained from female dorippus (27) or chrysippus (24), in most cases by placing a wild caught butterfly in a muslin bag over a branch of the foodplant, Calotropis gigantea (L.) Ait. (Asclepiadaceae), on which the larvae were also fed. Five broods were obtained from females which laid on Asclepias curassavica L. in an outdoor insectary. The generation time (egg-egg) is approximately 1 month.

Concurrently with the breeding programme, the population from which all the females were taken was sampled regularly for 26 months (approxi- 
mately the same number of overlapping generations) between February 1972 and March 1974 from three adjacent areas of rough grassland. Most collecting was done between 15.30 and 17.30 hours on sunny days to minimise variation due to daily rhythms and weather. Captured butterflies were marked and released so that none was counted twice (and for other purposes not considered here).
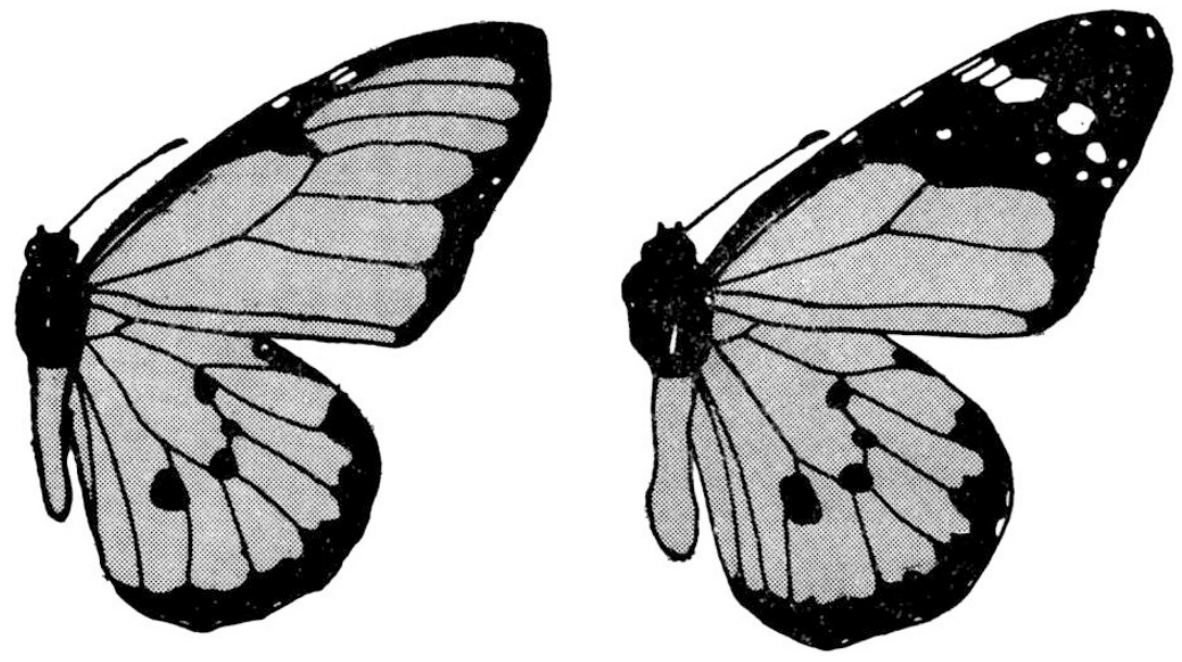

FIG. 1.-Danaus chrysippus morphs dorippus (left) and chrysippus. The specimens figured are males. Females have only the three anterior spots on the hindwing. Stippled areas are orange, the remainder being black and white as shown.

\section{Results}

The data in table 1, based on all 51 broods, show that female chrysippus produced a much higher proportion of female offspring than female dorippus (Yates' $\chi^{2}{ }_{(1)}=27.64 ; \mathrm{P}<0.001$ ). The distribution of normal (bisexual) and all-female broods in relation to the female parental morph is shown in table 2. In this case, all small broods $(<5)$ are omitted as a single sex brood of size 1-4 can reasonably be due to chance: the probability of a single sex brood as large as 5 is $\left(\frac{1}{2}\right)^{5}$ or 0.032 and, therefore, significant at the 5 per cent level. The 28 mixed broods had a total of 429 offspring, 204 males and 225 females $\left(\chi^{2}{ }_{(1)}=1.03 ; \quad P>0.30\right):$ as the heterogeneity $\chi^{2}$ is not significant $\left(\chi^{2}(27)=27.04 ; \mathrm{P}>0.30\right)$, the true sex ratio can be regarded as $1: 1$. Two individual broods showed significant deviations from $1: 1$, one in each direction, but this is not unexpected. It is clear that chrysippus females

TABLE 1

Sex of progeny obtained from females of two morphs of Danaus chrysippus

\begin{tabular}{llcc} 
& \multicolumn{2}{c}{ Female parent } & \\
\cline { 2 - 3 } Sex of progeny & $\overbrace{\text { Chrysippus }}$ & Dorippus & Total \\
Male & $50(80 \cdot 25)$ & $164(133 \cdot 75)$ & 214 \\
Female & $172(141 \cdot 75)$ & $206(236 \cdot 25)$ & 378 \\
Total & 222 & 370 & 592
\end{tabular}

Note-expected frequencies in parentheses. 
produced a higher proportion of all-female broods than dorippus females (Yates' $\chi^{2}(1)=7 \cdot 14 ; \mathrm{P}<0 \cdot 01$ ).

Two other butterfly species which regularly produce all-female broods have been reported. In Acraea encedon L. (Acraeidae) in tropical Africa, inheritance of the sex ratio effect is direct and matrilineal: females from allfemale broods always produce all-female broods, no case of reversion to bisexual broods having been recorded. Parthenogenesis, gynogenesis, $\mathrm{X}$-linked and autosomal inheritance have all been ruled out as possible controlling mechanisms, leaving two possibilities, Y-linked and cytoplasmic inheritance (Poulton, 1914; Owen, 1970; Owen and Chanter, 1971; Chanter and Owen, 1972). As the mean number of offspring per brood does not differ between normal and all-female broods, the former hypothesis

TABLE 2

Numbers of all-female and normal broods obtained from females of two morphs of Danaus chrysippus

\begin{tabular}{lccc} 
& \multicolumn{2}{c}{ Type of brood } & \\
Female parent & $\overbrace{\text { All-female }}$ & Normal & Total \\
Dorippus & $3(7 \cdot 67)$ & $19(14 \cdot 33)$ & 22 \\
Chrysippus & $12(7 \cdot 33)$ & $9(13 \cdot 67)$ & 21 \\
Total & 15 & 28 & 43
\end{tabular}

Note-expected frequencies in parentheses.

is favoured by Chanter and Owen (1972). On the other hand, in Hypolimnas bolina L. (Nymphalidae) from Fiji, Simmonds (1930) observed that a large percentage of eggs failed to hatch in all-female families, suggesting that inheritance is ultimately cytoplasmic and involves the death of male embryos.

The mechanism controlling the sex ratio effect in $D$. chrysippus was studied by establishing some members of an all-female brood, obtained from a wild form chrysippus female, in an outdoor insectary in which both foodplant for larvae and suitable flowers for the adults to feed from (Tridax procumbens L., Emilia coccinea (Sims) and garden Cosmos) were established. Several wild caught dorippus males were introduced to the cage containing four virgin females from brood 17. Mating occurred without delay, following which all but one pair were removed from the cage. The other mated females were retained in the laboratory for several days in case the chosen one failed to lay sufficient eggs. The line was maintained for five generations (table 3), a single pair founding the subsequent generation in every case.

Broods 25, 29 and 42 show that the dorippus colour pattern is dominant to chrysippus and brood 26 that the locus is not sex-linked, for if it were, all the female progeny would be chrysippus. Heterozygous dorippus are often phenotypically distinct from the homozygotes as they show traces of the chrysippus sub-apical row of spots on the underside of the forewing. It is therefore possible to take for breeding animals known to be heterozygous.

It is clear from the results shown in table 3 that the mechanism governing the inheritance of sex ratio in $D$. chrysippus differs from that in $A$. encedon. Mixed broods $(26,29)$ were produced in the third and fifth generations, the female parents of which came from all-female broods. Also, it is possible for a female from a mixed brood to produce an all-female brood (27). A further significant point is the absence of chrysippus males from broods 26 and 29 . 
The difference in sex ratio between the two morphs (broods 26 and 29 combined) is significant (Yates' $\chi^{2}(1)=6.00 ; \mathrm{P}<0.02$ ) : the overall sex ratio also shows a significant departure from the $1: 1$ expectation in the direction of females $\left(\chi^{2}(1)=5 \cdot 77 ; P<0 \cdot 02\right)$. Brood 51, the offspring of a dorippus $\times$ dorippus pair taken in the field, show a distribution similar to brood 29 with six dorippus males, four dorippus females and six chrysippus females. Three allfemale broods $(42,43,44)$ obtained from sisters (all-female brood 38) and each mated with males of different genotype (see table 3 ), suggest that the inheritance of the sex ratio effect is matrilineal and that the male has no influence on his own offspring in this regard. However, we see from broods

TABle 3

Broods of Danaus chrysippus mentioned in the text

\begin{tabular}{|c|c|c|c|c|c|c|}
\hline \multirow{3}{*}{$\begin{array}{c}\text { Brood } \\
\text { no. }\end{array}$} & \multicolumn{2}{|c|}{ Phenotype, genotype and source } & \multirow{2}{*}{\multicolumn{3}{|c|}{ Offspring }} & \multirow{3}{*}{$\begin{array}{l}\text { Segregation } \\
\text { for colour } \\
\text { locus }\end{array}$} \\
\hline & $\mathrm{Ma}$ & & & & & \\
\hline & parent & parent & Dor. $\sigma^{*}$ & Dor. 오 & Chrys. 우 & \\
\hline 17 & $\begin{array}{c}\text { (Dorippus (wild)) } \\
(C c S s \text { XX) }\end{array}$ & $\begin{array}{l}\text { Chrysippus (wild) } \\
\text { (ccss XYD) }\end{array}$ & 0 & $\begin{array}{c}3 \\
\text { CaSs } \mathrm{XYD}\end{array}$ & $\begin{array}{l}4 \\
\text { ccss XYD }\end{array}$ & $1: 1$ \\
\hline 25 & $\begin{array}{c}\text { Dorippus (wild) } \\
(\text { CCSS XX) }\end{array}$ & $\begin{array}{c}\text { Chrysippus (17) } \\
\text { ccss XYD }\end{array}$ & 0 & $\begin{array}{c}6 \\
C_{c} S s \mathrm{XYD}\end{array}$ & 0 & None \\
\hline 26 & $\begin{array}{l}\text { Chrysippus (23) } \\
\text { (ccss XX) }\end{array}$ & $\begin{array}{c}\text { Dorippus (25) } \\
\text { CoSs XYD }\end{array}$ & $\begin{array}{c}3 \\
\operatorname{Coss} \mathrm{xX}\end{array}$ & $\begin{array}{c}3 \\
C a S s \text { XYD }\end{array}$ & $\begin{array}{c}4 \\
\text { ccss } \mathrm{XYD}\end{array}$ & $1: 1$ \\
\hline 27 & $\begin{array}{c}\text { Dorippus (26) } \\
\text { CcSs XX }\end{array}$ & $\begin{array}{c}\text { Chrysippus (26) } \\
\text { ccss XYD }\end{array}$ & 0 & $\begin{array}{c}5 \\
\text { CaSs } \mathrm{XYD}\end{array}$ & $\begin{array}{c}7 \\
\operatorname{coss} \mathrm{XYD}\end{array}$ & $1: 1$ \\
\hline 29 & $\begin{array}{l}\text { Dorippus (wild) } \\
\quad(\text { CoSs XX) }\end{array}$ & $\begin{array}{c}\text { Dorippus (27) } \\
\text { CcSs XYD }\end{array}$ & $\begin{array}{c}9 \\
\operatorname{CCSS} \mathrm{XX} \\
\text { CaSs XX }\end{array}$ & $\begin{array}{c}11 \\
C C S S \text { XYD } \\
\text { C.SS XYD }\end{array}$ & $\begin{array}{c}9 \\
\operatorname{coss} \mathrm{XYD}\end{array}$ & $3: 1$ \\
\hline 38 & $\begin{array}{c}\text { (Dorippus (wild)) } \\
(\text { Ccss XX) }\end{array}$ & $\begin{array}{c}\text { Chrysippus (wild) } \\
\text { (ccss XYD) }\end{array}$ & 0 & (Coss XYD) & $\begin{array}{l}5 \\
\text { ccss } \mathrm{XY} D\end{array}$ & $1: 1$ \\
\hline 42 & $\begin{array}{l}\text { Dorippus (wild) } \\
\text { (CCSS XX) }\end{array}$ & $\begin{array}{l}\text { Chrysippus (38) } \\
\text { ccss XYD }\end{array}$ & 0 & $\begin{array}{c}16 \\
\operatorname{CcSS} \mathrm{XY} D\end{array}$ & 0 & None \\
\hline 43 & $\begin{array}{l}\text { Chrysippus (wild) } \\
\text { (ccss XX) }\end{array}$ & $\begin{array}{c}\text { Dorippus (38) } \\
\text { Ccss XYD }\end{array}$ & 0 & $\begin{array}{c}6 \\
\text { Coss } \mathrm{XY} D\end{array}$ & $\stackrel{4}{\text { ccss } \mathrm{XY} D}$ & $1: 1$ \\
\hline 44 & $\begin{array}{l}\text { Dorippus (wild) } \\
(\text { CoSs XX) }\end{array}$ & $\begin{array}{c}\text { Chrysippus ( } 38) \\
\text { ccss XYD }\end{array}$ & 0 & $\begin{array}{c}7 \\
\text { CoSs XYD }\end{array}$ & $\begin{array}{c}6 \\
\text { ccss } \mathrm{XYD}\end{array}$ & $1: 1$ \\
\hline
\end{tabular}

Gene symbols are explained in the text. Where a phenotype or genotype is in parentheses, it has been inferred from its offspring.

26 and 29 that, if the maternal male grandparent and female parent are both dorippus, reversion to a partially normal brood (chrysippus offspring being still all female) is possible. From brood 27, we infer that if the maternal male grandparent and the female parent are chrysippus, an all-female brood can result even if both parents come from mixed broods.

Parthenogenesis can safely be ruled out as the cause of all-female broods. Eggs obtained from unmated females have been invariably sterile. Also, segregation for colour occurs in the same way in both types of brood showing the equal contribution of male and female gametes. Cytoplasmic inheritance involving the elimination of male embryos, as seems to occur in $H$. bolina should be detectable as all-female broods would be on average smaller than normal broods. This matter has been investigated (table 4). All small broods $(<5)$ are omitted from this analysis for reasons given above, together with one very large brood to which two females may have contributed. 
As the raw data suggest that the different types of brood may differ in size, they are subjected to two-way analysis of variance (table 5). The calculated $F$ ratios show that the mean numbers of progeny produced by the four types of female cannot be regarded as equal. More offspring were reared from normal than all-female broods, and in broods from dorippus compared with chrysippus females. However, as the interaction $\mathrm{F}$ ratio is also significant, the two phenomena cannot be regarded as independent.

For all types of brood, the number of eggs laid was far in excess of the number of larvae successfully raised. In some broods, many eggs failed to

TABLE 4

Number of offspring per brood reared from four types of Danaus chrysippus females

$\begin{array}{lccc}\begin{array}{c}\text { Female morph and } \\ \text { brood type }\end{array} & \begin{array}{c}\text { Number of } \\ \text { broods }\end{array} & \begin{array}{c}\text { Total } \\ \text { progeny }\end{array} & \begin{array}{c}\text { Mean and } \\ \text { standard error }\end{array} \\ \text { Dorippus normal } & 17 & 276 & 16 \cdot 24 \pm 2 \cdot 40 \\ \text { Chrysippus normal } & 9 & 100 & 11 \cdot 11 \pm 1 \cdot 74 \\ \text { Dorippus all o } & 3 & 24 & 8 \cdot 00 \pm 4 \cdot 16 \\ \text { Chrysippus all } q & 12 & 117 & 9 \cdot 75 \pm 2 \cdot 08\end{array}$

TABLE 5

Analysis of variance for table 4

$\begin{array}{lrccc}\begin{array}{l}\text { Sources of } \\ \text { variation }\end{array} & \begin{array}{c}\text { Sums of } \\ \text { squares }\end{array} & \begin{array}{c}\text { Degrees of } \\ \text { freedom }\end{array} & \begin{array}{c}\text { Mean } \\ \text { squares }\end{array} & \begin{array}{c}\text { Variance } \\ \text { ratio }\end{array} \\ \text { Morphs } & 223 \cdot 10 & 1 & 223 \cdot 10 & 4 \cdot 308^{*} \\ \text { Brood types } & 243 \cdot 69 & 1 & 243 \cdot 69 & 4 \cdot 705^{*} \\ \text { Interaction } & 336 \cdot 89 & 1 & 336 \cdot 89 & 6 \cdot 505^{*} \\ \text { Error } & 1916 \cdot 08 & 37 & 51 \cdot 79 & * \mathrm{P}<0 \cdot 05 \\ \text { Total } & 2719 \cdot 76 & 40 & - & -\end{array}$

hatch, probably because females run out of sperm (they may mate several times in the wild). Larval mortality was very high in all broods over a 2-month period, probably resulting from virus disease. Also, dry season broods are subject to loss because the larvae appear to find the foodplant unpalatable. The various problems encountered in rearing larvae may have obscured real differences in fecundity, but no consistent or clear-cut differences of brood size between brood types, such as would be required to support cytoplasmic inheritance, were detected.

The mechanics of all-female broods probably involve abnormal gametogenesis in the female (the heterogametic sex in Lepidoptera) whereby the $\mathrm{X}$ chromosome always enters the first polar body at meiosis, leaving the $\mathrm{Y}$ in the secondary öocyte. This is called meiotic drive (Hamilton, 1967). It has been pointed out that a gene giving meiotic drive for $\mathrm{Y}$ would spread very rapidly through a population causing its extinction through lack of males (in Lepidoptera), and that the acquisition of a suppressor gene would be necessary to save it (Owen and Chanter, 1972).

A sex ratio model for $D$. chrysippus must take into account the following facts: (1) inheritance of the effect is matrilineal but males can be carriers (table 3 , brood 26); (2) there is an association between brood type and the forewing colour locus; (3) within the same brood, sex ratio may be normal in one colour morph and all-female in the other; (4) an all-female line can revert to a bisexual one or vice versa. Two models are proposed which fit all the facts known to date. 
In the first model, worked out in table 3 , the gene $D$ giving meiotic drive is Y-linked. There is a suppressor gene $(S)$, linked to the forewing colour locus, which has two alleles, $C$ giving dorippus and $c$ chrysippus. As suppression (i.e. bisexual brood) is associated with dorippus, of which all individuals in broods 17, 25, 26 and 27 are known to be heterozygous at the colour locus, $S$ must be dominant and its recessive allele $(s)$ will most often be linked with c. Genes $S$ and $C$ are likewise usually linked in coupling. Heterozygous dorippus females ( $C_{C} S s$ XYD), such as the female parents of broods 26 and 29, are able to form only three kinds of gamete in the absence of crossing over, $C S \mathrm{X}$, cs $\mathrm{Y} D$ and $C S \mathrm{Y} D$ : cs $\mathrm{X}$ nuclei, resulting from the segregation cs $\mathrm{X} / C S \mathrm{Y} D$, which would give chrysippus males if the male parent was either chrysippus (brood 26) or heterozygous dorippus (brood 29), always enter the first polar body as they do not contain a driving $\mathrm{Y}$ suppressor. In other words, all X nuclei segregating from YD at öogenesis must carry $S$ to avoid being shunted into the polar body. CcSs XYD females can. therefore, produce dorippus but not chrysippus males in the absence of recombination, which may be rare if there is close linkage. In this model, chrysippus females producing normal broods could be either a repulsion phase $(c c S-\mathrm{XY} D)$ or lacking gene $D$.

An alternative model has meiotic drive controlled by a recessive gene $(d)$, linked with the colour locus, normally in coupling with $c$. A suppressor could be carried on any other chromosome. The system would not even require a suppressor if chrysippus had an increasing selective disadvantage as population density built up (density-dependent selection) although this would leave the genetic mechanism controlling segregations such as in broods 26, 29 and 51 unaccounted for. Moreover, selection against form chrysippus would have to be powerful to outweigh its reproductive advantage. In favour of this model is the fact that there is no certain example of $\mathrm{Y}$ chromosome inheritance known in Lepidoptera. Clarke and Sheppard (1959) believed the inheritance of black and yellow forms of female Papilio glaucus L. might be controlled in this way, but cytoplasmic inheritance was not ruled out. However, the disadvantage of the second model, which applies to any of a number of other possible models not involving $\mathrm{Y}$ chromosome inheritance, is that it fails to take sufficiently into account the strong evidence for matrilineal descent of the sex ratio effect.

The results of the field sampling are shown in fig. 2. It is apparent that both sex and morph ratios are subject to continuous and sometimes very rapid change. Although the species has a continuous distribution over large areas, within which discrete populations are not formed, there is no evidence that these changes are the result of migration. Females reach a peak frequency twice a year (April and December-January) corresponding with the start of the two rainy seasons, each of which are periods of rapid population growth. Peak frequencies of chrysippus also occur twice a year in JuneJuly and December (1972). With the exception of December 1972, peak frequencies of females preceded those of chrysippus by 1-3 months. The timelag and its variable duration vitiate any attempt to demonstrate a correlation between the two phenomena. In the light of the genetic evidence, however, it is probable that they are causally connected. In February-April and October-November, when the population density, frequency of chrysippus and proportion of females are all low, most cs chromosomes (first model) must be carried by heterozygous dorippus (CCSS, CCSs or Ccss) females which 
may also have gene $D$ (its frequency is unknown). In the period of population growth (April-July) these females pair non-randomly, chrysippus o $\times$ dorippus $q$ matings being commoner than expected (Smith, 1973b; 1975). If the female is either CcSs XYD or Ccss XYD, 1:1 segregations for dorippus: chrysippus would result wherein the chrysippus offspring were all female from the former female genotype and all offspring female from the latter. My hypothesis is that the arrival of rain accompanied by new growth

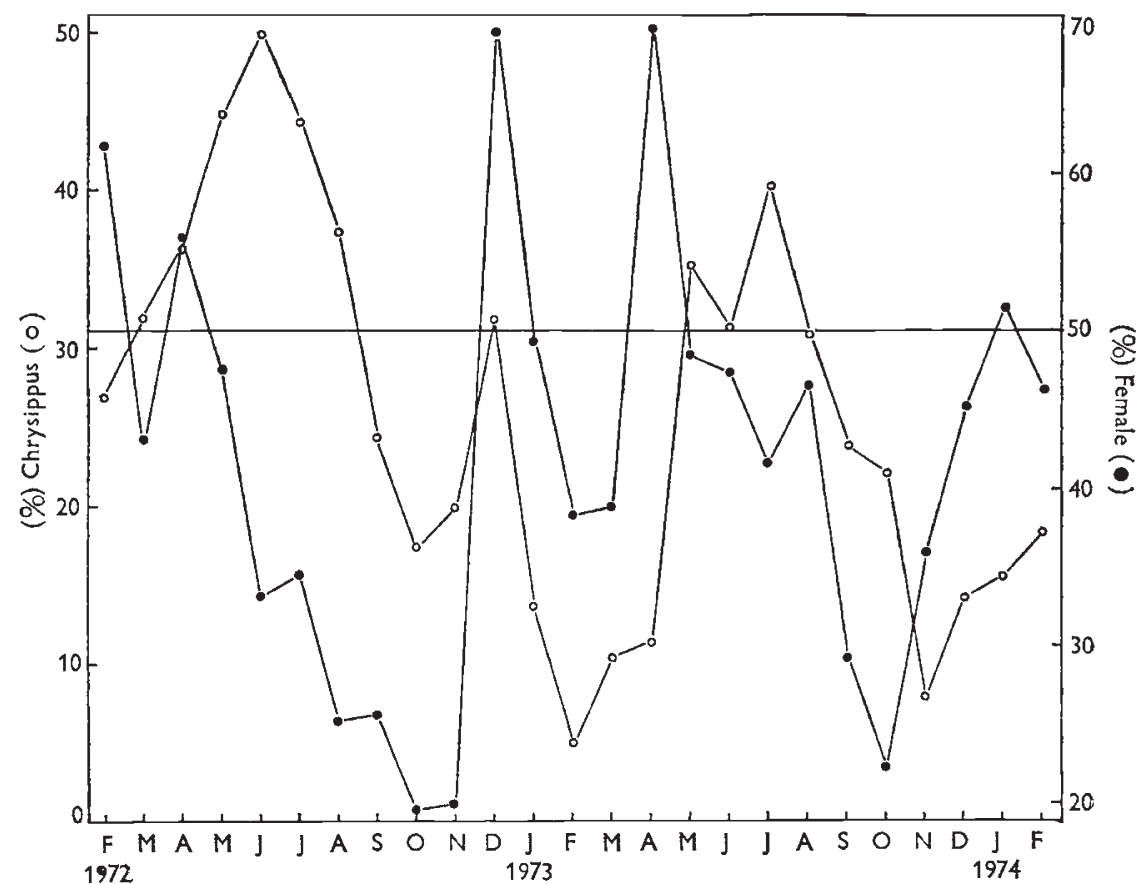

Fig. 2.-The frequency of females (O) and morph chrysippus (O) of Danaus chrysippus sampled in the field at Dar-es-Salaam between February 1972 and February 1974.

of foodplant, favours chrysippus females because of their contribution to the population growth which occurs under conditions of relaxed selection on individuals. A similar sudden reversal of sex ratio at the start of the rains is described by Owen (1974) in Acraea quirina (F.) from Sierra Leone. My results suggest that, in most cases, selection for low sex ratio lasts for little more than a single generation ( 1 month), after which it is sharply reversed, whereas selection for chrysippus (both sexes) has a duration of 2-4 months.

Sexual selection for chrysippus males occurred in the period April-June (or July) in both 1972 and 1973. In 1973, sexual selection for dorippus males followed in August-September when population growth had ceased. For the remainder of both years there was selective neutrality in terms of mating advantage (Smith, 1975). There is also evidence of sexual selection for chrysippus females (and, therefore, for all-female broods) in December 1972 (Smith, 1975) and April 1974 and for dorippus females at other times. These facts suggest that sexual behaviour is of major significance in determining both morph and sex ratios. 


\section{Discussion}

Extreme fluctuations in population density are a well-known feature of multivoltine, tropical insect populations and are often related to alternating extremes of rain or drought. In such circumstances, any species which is able to expand its numbers fast and without delay in response to favourable conditions, is likely to be successful. Distortion of the sex ratio in favour of females is one of a number of reproductive mechanisms capable of achieving this end. It must be of particular value where seasonal weather cycles are erratic as in coastal Tanzania. Here, both wet seasons are variable in timing and amplitude and prolonged wet or dry periods may occur in any month. Moreover, species such as $D$. chrysippus which are particularly characteristic of areas disturbed by man (agricultural land and gardens) are likely to be favoured if they can expand rapidly into the altered habitats he continually creates. At times of fairly high population density each male may mate with up to five females (unpublished observations) and so a high female/male ratio will favour population growth. If, on the other hand, individuals are widely scattered, many females in a predominantly female population may remain unmated (Owen, Owen and Chanter, 1973); therefore, selection should favour normal segregation for sex. In $D$. chrysippus this leads to a large excess of males in the field, probably due to their superior survival (see fig. 2, October, November, February and March when population density was lowest).

Since $D$. chrysippus is polymorphic for all-female and bisexual broods, regulation of the balance between the two types of female can contribute to both rapid expansion and stabilisation of numbers in response to environmental conditions. The colour polymorphism, the genetic control of which is linked, probably closely and possibly completely, with that for sex ratio, is subject to selection in such a way that selective advantage alternates seasonally between two visually contrasted morphs. A mechanism therefore exists whereby the reproductive response to altered conditions could be quite rapid. Disassortative mating, which has been demonstrated in the same population over a 6 month period (February-July 1972) (Smith, 1973b), by maximising heterozygosity, would increase its ability to respond rapidly at the outset of a population growth phase. Conversely, positive assortative mating which followed (Smith, in preparation) could reverse the trend. Kalela and Oksala (1966) show that sex ratio in the wood lemming (Myopus schisticolor Lilljeb.) is polymorphic in the same way as $D$. chrysippus. Low sex ratios are associated with periods of population expansion and normal sex ratios with their decline. It seems that unusual sex ratios in other species should now be examined, not only for their genetic interest, but also to discover if they function as intrinsic population regulators. The genetic system outlined here in $D$. chrysippus is essentially a negative feedback mechanism functioning as an homeostatic device at the population level. However, selection operates on individuals as usual, demonstrably in the form of mating behaviour and probably in other ways as well. The mechanism provides a genetic explanation for the ecological theory of density-dependent population regulation as applied to $D$. chrysippus.

Acknowledgment.- I am most grateful to Dr J. A. Allen, Dr D. M. Pearson and Professor D. F. Owen for assistance with sampling and valuable discussion. 


\section{REFERENGES}

CHANTER, D. O., AND OWEN, D. F. 1972. The inheritance and population genetics of sex ratio in the butterfly Acraea encedon. 7. Zool. Lond., 166, 363-383.

CLARKE, C. A., AND SHEPPARD, P. M. 1959. The genetics of some mimetic forms of Papilio dardanus Brown and Papilio glaucus Linn. 7. Genet., 56, 236-260.

Hamlton, W. D. 1967. Extraordinary sex ratios. Science, Wash., 156, 477-488.

Kalel.a, O., AND oksal.a, T. 1966. Sex ratio in the wood lemming Myopus schisticolor (Lilljeb.) in nature and in captivity. Ann. Universitatis Turkuensis, Ser. A II. BiologicaGeographica, 1-24.

oWen, D. F. 1970. Inheritance of sex ratio in the butterfly Acraea encedon. Nature, Lond., $225,662-663$.

OWEN, D. F. 1974. Seasonal change in sex ratio in Acraea quirina (F.) (Lep. Nymphalidae), and notes on the factors causing distortions of sex ratio in butterflies. Ent. scand., 5, $110-114$.

OWEN, D. F., AND CHANTER, D. O. 1968. Population biology of tropical African butterflies. 2. Sex ratio and polymorphism in Danaus chrysippus L. Rev. Zool. Bot. afr., 78, 81-97.

OWEN, D. F., AND CHANTER, D. O. 1971. Polymorphism in West African populations of the butterfly Acraea encedon. 7. Zool. Lond., 163, 481-488.

OWEN, D. F., OWEN, J., AND CHANTER, D. O. 1973. Low mating frequencies in an African butterfly. Nature, Lond., 244, 116-117.

poulton, E. B. 1914. W. A. Lambourn's breeding experiments upon Acraea encedon (Linn.) in the Lagos district of West Africa, 1910-1912. F. Linn. Soc. Lond. (Zool.), 32, 391-416.

simmonds, H. w. 1930. Further notes on Hypolimnas bolina L. in Fiji. Proc. R. ent. Soc. Lond., $5,75-77$.

SMrTH, D. A. s. 1973a. Batesian mimicry between Danaus chrysippus and Hypolimnas misippus (Lepidoptera) in Tanzania. Nature, Lond., 242, 129-131.

SMTTH, D. A. s. 1973b. Negative non-random mating in the polymorphic butterfly Danaus chrysippus in Tanzania. Nature, Lond., 242, 131-132.

SMrTH, D. A. s. 1975. Sexual selection in a wild population of the butterfly Danaus chrysippus L. Science, Wash., 187, 664-665. 